Original Research

\title{
Methane-Oxidizing Microorganism Properties in Landfills
}

\author{
Juan Mei ${ }^{1,2,3 *}$, Yining Wu1, Feiyue Qian", ${ }^{1,}$ Chongjun Chen ${ }^{1,2}$, \\ Yaoliang Shen ${ }^{1,2}$, Youcai Zhao ${ }^{4}$ \\ ${ }^{1}$ College of Environmental Science and Engineering, Suzhou University of Science and Technology, \\ Suzhou, P.R. China \\ ${ }^{2}$ National and Local Joint Engineering Laboratory of Municipal Sewage Resource Utilization Technology, \\ Suzhou, P.R. China \\ ${ }^{3}$ Jiangsu Collaborative Innovation Center of Technology and Material of Water Treatment, Suzhou, P.R. China \\ ${ }^{4}$ State Key Laboratory of Pollution Control and Resources Reuse, Tongji University, \\ Shanghai, P.R. China
}

Received: 29 May 2018

Accepted: 23 September 2018

\begin{abstract}
Bio-oxidation of methane in a landfill environment is important for mitigating global methane emissions into the atmosphere. In the present study, the characteristics of methane bio-oxidation and methane-oxidizing microorganisms were studied by enrichment cultivation using fresh and aged leachate (collected from Qizishan Landfill, Suzhou, China). Both aerobic and anaerobic methane oxidation were detected, methane oxidation capacities of the culture liquid were $5.24-7.26 \mu \mathrm{mol} / \mathrm{mL} / \mathrm{d}$ under aerobic conditions and 4.41-3.70 $\mu \mathrm{mol} / \mathrm{mL} / \mathrm{d}$ under anaerobic conditions. The stoichiometry of anaerobic oxidation of methane (AOM) showed the complexity of AOM mechanisms in the leachate culture, with the types of sulfate-dependent, denitrification-dependent and iron-dependent AOM. The 16S rRNA gene sequence analysis and SEM analysis results showed that the genus Methylocystis was the dominant bacteria in aerobic cultures (relative abundance 35.96-78.37\%). Genus Moheibacter (41.38\%) and Cupriavidus (43.08\%) were the most dominant taxa in anaerobic cultures, with aerobic methanotrophs Methylocaldum and Methylocystis in low abundance, and no anaerobic methane-oxidizing archaea (ANME) was found. Further research is needed to confirm whether aerobic methanotrophs can oxidize methane under anaerobic conditions.
\end{abstract}

Keywords: landfill, methane oxidation, leachate, methane-oxidizing microorganisms, methanotrophs, anaerobic oxidation of methane

*e-mail: susie_mei@163.com 


\section{Introduction}

Methane is a well-known greenhouse gas. Atmospheric methane concentration has more than doubled since the preindustrial era, from approximately $0.7 \mathrm{ppm}$ to about $1.8 \mathrm{ppm}$ today. Approximately $60 \%$ of its global emissions are derived from human activity $[1,2]$. According to estimates from the International Panel on Climate Change, the global release of methane was approximately $3 \times 10^{11} \mathrm{~kg}$ in 2000 and has continued to increase. Refuse landfill sites are significant sources of methane release and account for $6-12 \%$ of global methane emissions [3]. Hence, on-site control of methane emissions in refuse landfill sites has been highlighted.

The methane oxidation capability of landfill covers has been studied, with the final cover demonstrating effective reduction of methane release $[4,5]$. The feasibility of various materials to enhance methane oxidation capacity of landfill covers has been investigated [6-9]. Aged refuse from waste landfills closed for 8 years was found to contain methanotrophs capable of methane bio-oxidation $[8,10]$. Both Type I and II methanotrophs were found in the aged refuse, including the genus Methylobacter, Methylocaldum, and Methylocystis [10]. These findings suggest that methanotrophs may be present inside the landfill.

Many studies have shown that some methane that was previously thought to be consumed by aerobic oxidation was actually consumed by anaerobic oxidation of methane (AOM) [11-13]. Subsequent studies found that AOM is widespread and has been detected in various environments, including landfills and the surrounding environment [14-18]. AOM was discovered in an alluvial aquifer contaminated with leachate from an unlined municipal landfill $[19,20]$. The rate of AOM at this site was 1-3 orders of magnitude lower than that in ocean sediments with rich sulfate, and 3 orders of magnitude lower than that of aerobic oxidation of methane in the landfill cover [19]. Han found that sulfate-reducing bacteria (SRB) existed in almost all layers of landfill bodies, and aged refuse at the bottom contained most [21]. Both aerobic and anaerobic methane oxidation effects were detected in garbage samples, with anaerobic oxidation accounting for more than $20 \%$.

AOM has been considered important for controlling global methane emissions. There has been much research on AOM in deep sea and sediments, and ANME are thought to couple methane oxidation to sulfate reduction in partnership with SRB in the deep sea [22-24]. The findings of AOM in various environments, such as lake sediments, a contaminated aquifer, and a mud volcano, have deepened our understanding of its mechanisms [25-28]. The anaerobic oxidation of methane may influence methane emissions in a landfill because the anoxic region is prevalent in this environment. But little is known about methane oxidation in a landfill, and its mechanism and the related microorganisms are not clear.
Therefore, the AOM mechanism in landfills and related microbial populations should be investigated. In this study, leachate was used to enrich methaneoxidizing microorganisms to reveal the characteristics of the methane oxidation community in the landfill at different refuse degradation phases, and the AOM mechanism was discussed by stoichiometric analysis. This research provided useful reference for further study of the anaerobic oxidation process and microorganisms in a landfill. It is helpful for understanding the carbon conversion process within the landfill and providing guidance for effective methane emissions control at landfill sites.

\section{Materials and Methods}

\section{Enrichment Cultivation of Methane-Oxidizing Microorganisms}

Two types of leachate were used for enrichment cultivation: leachate M1, during the hydrolysis acidification stage, was collected from a laboratory simulation landfill lysimeter containing refuse that had been sealed for over 6 months; and leachate M2 was collected from Qizishan Landfill (with a cover time of over 8 years) in Suzhou, China (Fig. 1). The leachate of 6 months is not a typical environment for methaneoxidizing bacteria, but significant methane oxidation was observed in the leachate of this stage in our previous experiments, so leachate of 6 months was used for enrichment experiments here.

Materials packed in the lysimeter were prepared according to the organic composition of refuse in landfill sites [29], and consisted of 70\% kitchen waste, $20 \%$ paper, and $10 \%$ wood and fabric. The main properties of the material were as follows: a moisture content of approximately $70 \%$ and a density of approximately $235 \mathrm{~kg} / \mathrm{m}^{3}$. The prepared household waste was broken down before being mixed and placed in the lysimeter, which was then sealed. The experimental rig was made according to Mei [10].

Leachate was used to inoculate nitrate minimal salt (NMS) medium to enrich methane-oxidizing microorganisms [10]. Enrichments were carried out by batch incubation experiments using two methods: under aerobic conditions and under anaerobic conditions. Samples MO1 and MO2 are cultures enriched with leachate M1 and M2 under aerobic conditions; MA1 and MA2 are cultures enriched with leachate M1 and M2 under anaerobic conditions. Leachate $(2 \mathrm{~mL})$ and $15 \mathrm{~mL}$ NMS medium were placed in $300 \mathrm{~mL}$ serum bottles. For aerobic cultivation, the serum bottles were sealed with rubber stoppers and $50 \mathrm{~mL}$ methane was injected to replace the air in the bottle. For anaerobic cultivation, leachate and NMS medium were anaerobically transferred into the bottle with $2 \mathrm{~mL}$ $\mathrm{Na}_{2} \mathrm{SO}_{4}(0.125 \mathrm{~mol} / \mathrm{L})$ added as an electron acceptor, the bottles were swept with nitrogen for $15 \mathrm{~min}$, 


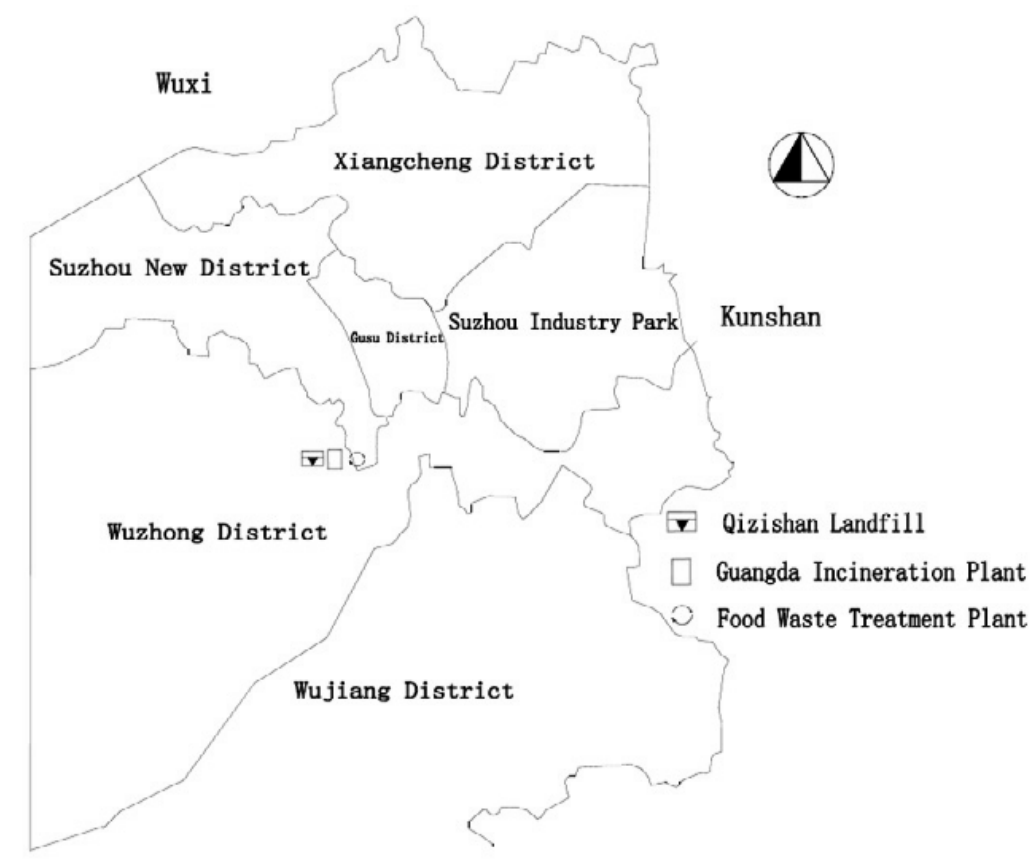

Fig. 1. The location of Suzhou Qizishan Landfill, which disposes municipal solid waste in Suzhou New District, Suzhou Industry Park, Gusu District, Xiangcheng District and Wuzhong District.

sealed with rubber stoppers and injected with $50 \mathrm{~mL}$ methane. All bottles were incubated at $36^{\circ} \mathrm{C}$, on a rotary shaker operating at $130 \mathrm{rpm}$. High methane oxidation rates were found to be between 28 and $37^{\circ} \mathrm{C}$ in our previous research [8], therefore methane-oxidizing microorganisms were enriched at $36^{\circ} \mathrm{C}$ in this study. Methane concentrations in the bottles were analyzed before and after enrichment to determine methane oxidation rates. Each culture included three parallel samples.

\section{DNA Extraction, PCR, and Pyrosequencing}

The cultures with the highest methane oxidation rate were prepared for DNA extraction. The culture liquid was centrifuged $(8,000 \times \mathrm{g}, 3 \mathrm{~min})$ and DNA was extracted from the deposit using the E.Z.N.A. Soil DNA Isolation Kit (Omega Bio-Tek, Inc., USA). The bacterial primers 338F (5'-ACTCCTACGGGAGGCAGCA-3') and 806R (5'-GGACTACHVGGGTWTCTAAT-3') were used to amplify the V3-V4 region of the 16S rRNA gene. Archaea community analysis was conducted using the bacterial primers Arch334F (5'-ACGGGGYGCAGCAGGCGCGA-3') and Arch915R (5'-GTGCTCCCCCGCCAATTCCT-3').

The pmoA gene was PCR amplified from total DNA extracted from the same samples using primer mb661 in conjunction with primer A189gc [30, 31]. Primers $\mathrm{A} 189 \mathrm{gc}$ and mb661 can amplify an approximately 470-bp internal section of pmoA and produce strong signals with many methanotrophs. The PCR amplification reactions were carried out using previously published laboratory protocols [31].

\section{Nucleotide Sequence Accession Numbers}

High-throughput pyrosequencing was performed on the Illumina MiSeq platform at Majorbio Bio-Pharm Technology Co., Ltd., China. The GenBank accession numbers for the nucleotide sequences determined in this study were MH177848 to MH177850.

\section{Scanning Electron Microscopy (SEM)}

The culture liquid was centrifuged $(8,000 \times \mathrm{g}, 3 \mathrm{~min})$ and the deposits were washed using $0.1 \mathrm{M}$ phosphoric acid buffer (PHB) three times, and were then fixed using $2.5 \%$ glutaraldehyde solution $(\mathrm{pH} 6.8)$ at $4^{\circ} \mathrm{C}$ for $12 \mathrm{~h}$. The fixed samples were washed again with PHB three times for 5 min each time, then dehydrated by covering the samples with 30, 50, 70, 90 and $95 \%$ ethanol for $10 \mathrm{~min}$ each time and finally dehydrated with $100 \%$ ethanol three times. Air-dried samples were placed on aluminum specimen mounts and were gold sputtered and viewed with a Hitachi S-3200N scanning electron microscope operating at $20 \mathrm{kV}$.

\section{Chemometrics Analysis of Anaerobic Methane Oxidation}

Besides the added $\mathrm{Na}_{2} \mathrm{SO}_{4}$, nitrate and sulfate are components of NMS medium and can also serve as electron acceptors for AOM according to reported AOM mechanisms [32-34]. Phosphate is also considered a potential electron acceptor. The concentrations of these electron acceptors in NMS medium were calculated as $\mathrm{n}$ $\mathrm{Na}_{2} \mathrm{SO}_{4}, \mathrm{n} \mathrm{NO}_{3}^{-}, \mathrm{n} \mathrm{SO}_{4}^{2-}$, and $\mathrm{nO}_{4}^{3-}$, respectively. 
Below are the chemometrics of anaerobic methane oxidation related to sulfate reduction, nitrate reduction and phosphate reduction, respectively:

$$
\begin{gathered}
\mathrm{CH}_{4}+\mathrm{SO}_{4}^{2-} \rightarrow \mathrm{HCO}_{3}^{-}+\mathrm{HS}^{-}+\mathrm{H}_{2} \mathrm{O} \\
5 \mathrm{CH}_{4}+8 \mathrm{NO}_{3}^{-}+8 \mathrm{H}^{+} \rightarrow 5 \mathrm{CO}_{2}+4 \mathrm{~N}_{2}+14 \mathrm{H}_{2} \mathrm{O} \\
\mathrm{CH}_{4}+\mathrm{PO}_{4}^{3-} \rightarrow \mathrm{HCO}_{3}^{-}+\mathrm{H}_{3} \mathrm{P}
\end{gathered}
$$

According to the above equations, the equivalent quantity of the electron acceptors of moles of methane are shown below, calculated as $\mathrm{N} \mathrm{Na}_{2} \mathrm{SO} 4, \mathrm{~N} \mathrm{NO}_{3}^{-}, \mathrm{N}$ $\mathrm{SO}_{4}^{2-}$, and $\mathrm{N} \mathrm{PO}_{4}^{3-}$, respectively.

$$
\begin{gathered}
\mathrm{N} \mathrm{SO}_{4}{ }^{2-}=\mathrm{n} \mathrm{SO}_{4}{ }^{2-} \\
\mathrm{N} \mathrm{NO}_{3}^{-}=0.625 \mathrm{n} \mathrm{NO}_{3}^{-} \\
\mathrm{N} \mathrm{PO}_{4}{ }^{3-}=\mathrm{n} \mathrm{PO}_{4}{ }^{3-}
\end{gathered}
$$

The total number of possible electron acceptors in NMS medium (counted as $\mathrm{Ne}$ ) was calculated by Eq. (7):

$$
\begin{gathered}
\mathrm{Ne}=\mathrm{n} \mathrm{Na}_{2} \mathrm{SO}_{4}+\mathrm{n} \mathrm{SO}_{4}^{2-}+ \\
0.625 \mathrm{n} \mathrm{NO}_{3}^{-}+\mathrm{n} \mathrm{PO}_{4}^{3-}
\end{gathered}
$$

\section{Analytical Methods}

$\mathrm{CH}_{4}$ was analyzed in a $200 \mu \mathrm{L}$ sample by gas chromatography (GC-14B, Shimadzu, Japan) with a stainless steel column packed with Carbosive SII (diameter of $3.2 \mathrm{~mm}$ and $2.0 \mathrm{~m}$ length) and thermal conductivity detector (TCD). The temperature of the injection, column and detector was set at 40,80 and $90^{\circ} \mathrm{C}$, respectively. The carrier was nitrogen and the flow rate was $30 \mathrm{~mL} / \mathrm{min}$.

For the leachate, total nitrogen (TN) was measured according to the distillation-titration method; total

Table 1. Physicochemical properties of the leachate.

\begin{tabular}{|c|c|c|c|}
\hline \multirow{2}{*}{ Parameter } & \multirow{2}{*}{ Unit } & $\begin{array}{c}\text { Leachate } \\
\text { M1 }\end{array}$ & $\begin{array}{c}\text { Leachate } \\
\text { M2 }\end{array}$ \\
\cline { 4 - 4 } & & $7.90 \pm 0.18$ & $7.70 \pm 0.17$ \\
\hline pH & $\mathrm{mV}$ & $-52 \pm 17$ & $-38 \pm 10$ \\
\hline $\mathrm{TOC}$ & $\mathrm{mg} / \mathrm{L}$ & $295.4 \pm 7.5$ & $27.8 \pm 1.1$ \\
\hline $\mathrm{IC}$ & $\mathrm{mg} / \mathrm{L}$ & $361.6 \pm 36.9$ & $568.5 \pm 7.4$ \\
\hline $\mathrm{TN}$ & $\mathrm{mg} / \mathrm{L}$ & $32.0 \pm 7.2$ & $1986.5 \pm 52.1$ \\
\hline $\mathrm{TP}$ & $\mathrm{mg} / \mathrm{L}$ & $0.20 \pm 0.02$ & $0.26 \pm 0.02$ \\
\hline $\mathrm{Fe}$ & $\mathrm{mg} / \mathrm{L}$ & $0.44 \pm 0.06$ & $1.66 \pm 0.22$ \\
\hline $\mathrm{Mn}$ & $\mathrm{mg} / \mathrm{L}$ & $0.49 \pm 0.03$ & $0.27 \pm 0.02$ \\
\hline
\end{tabular}

phosphate (TP) was determined by the molybdate spectrophotometric method [35]; TOC was determined by TOC-VCPH/CPN (Shimadzu Corporation, Japan), oxidation reduction potential (ORP) was measured using an ORP electrode with a special $\mathrm{pH}$ meter for $\mathrm{mV}$ readings, negative ion concentrations were analyzed by ICS-1000 (Dionex corporation, USA), and metal ion concentrations were measured by Optima 2100 DV (Perkin Elmer) after microwave digestion by ETHOSE (Mile Stones.r.1, Italy) [36].

\section{Results and Discussion}

Physicochemical Properties of the Leachate Used for Enrichment Cultivation

Table 1 shows the main physicochemical properties of leachates M1 and M2. M1 sampled from a landfill and simulating a lysimeter sealed for over 6 months represents fresh leachate during the hydrolysis acidification phase of organic decomposition. M2 represents aged leachate of over 8 years.

\section{Methane Oxidation Activity under Different Cultivation Conditions}

The method of inoculating leachate into NMS medium to enrich methane oxidation microorganisms was feasible. Both aerobic methane oxidation and anaerobic methane oxidation were observed in the cultivation experiments (Fig. 2). The oxidation rates of the anaerobic culture liquid were $36.28-39.40 \%$ in 14 days, lower than those of the aerobic culture liquid (55.84-77.31\%). Methane oxidation rates of fresh leachate samples were higher than those of aged leachate samples. For investigating the AOM mechanism, laboratory enrichment cultures of the responsible

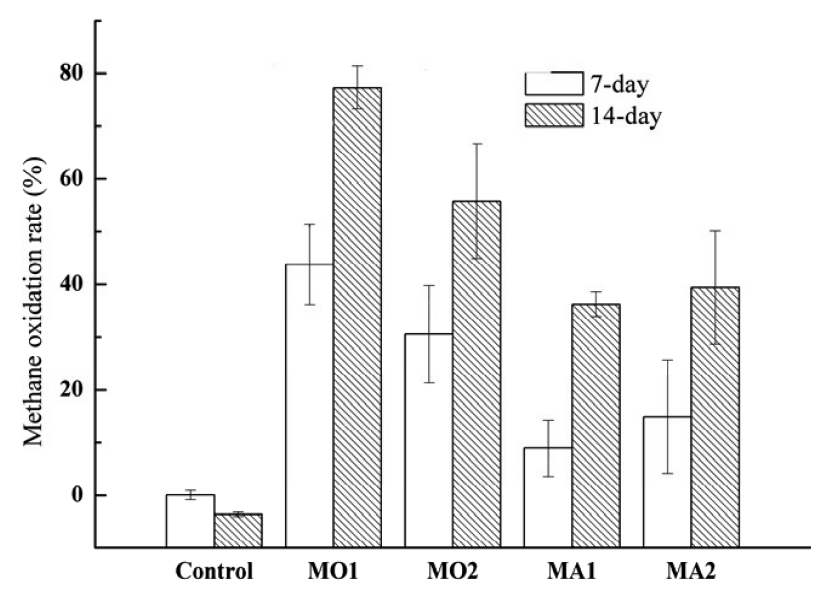

Fig. 2. Methane oxidation rates of different enrichment cultures: $\mathrm{MO} 1$ and MO2 are cultures enriched with leachate M1 and M2 under aerobic conditions; MA1 and MA2 are cultures enriched with leachate M1 and M2 under anaerobic conditions. 
Table 2. Stoichiometry of oxidized methane and different electron acceptors in the cultivation system.

\begin{tabular}{|c|c|c|c|c|c|}
\hline \multirow{2}{*}{$\begin{array}{c}\text { Number of } \\
\text { reactants/ } \\
\text { mmol }\end{array}$} & \multirow{2}{*}{$\mathrm{CH}_{4}$} & \multicolumn{4}{|c|}{ Possible electron acceptors } \\
\cline { 2 - 6 } & 1.972 & $\mathrm{Na}_{2} \mathrm{SO}_{4}$ & $\mathrm{SO}_{4}^{2-}$ & $\mathrm{NO}_{3}^{-}$ & $\mathrm{PO}_{4}^{3-}$ \\
\hline \multirow{2}{*}{$\begin{array}{c}\text { Maximum possible } \\
\text { oxidation rate }\end{array}$} & $12.7 \%$ & 0.035 & 0.193 & 0.300 \\
\cline { 2 - 6 } & \multicolumn{3}{|c|}{$14.5 \%$} & & \\
\cline { 2 - 5 } & \multicolumn{4}{|c|}{$24.3 \%$} & \\
\cline { 2 - 5 } & \multicolumn{4}{|c}{$39.5 \%$} \\
\hline
\end{tabular}

microorganisms are of crucial importance. High methane oxidation rate of the leachate culture suggested that anaerobic methane oxidation microorganisms in the landfill were enriched successfully here.

According to the ideal gas state equation, the initial methane amount $\left(\mathrm{n}_{\mathrm{CH} 4}\right)$ in the serum bottle in the enrichment cultivation test can be calculated. In this experiment temperature, pressure and the volume of methane injected in the bottles were $309 \mathrm{~K}, 101.1$ $\mathrm{KPa}$, and $50 \mathrm{~mL}$, respectively. The initial methane amount $\left(\mathrm{n}_{\mathrm{CH} 4}\right)$ was approximately $1.972 \mathrm{mmol}$. Based on $\mathrm{n}_{\mathrm{CH} 4}$, the average methane oxidation capacities under anaerobic conditions were 3.41-3.70 $\mu \mathrm{mol} / \mathrm{mL} / \mathrm{d}$. These values were higher than those observed in other studies [18, 34]. Scheller et al. studied AOM in deepsea sediments. They performed anaerobic microcosm experiments using methane seep sediment (containing ANME-2a and ANME-2c). After 21 days incubation at $4^{\circ} \mathrm{C}$, the initial rates of $\mathrm{AOM}$ with different electron acceptors were $0.12-1.62 \mu \mathrm{mol} / \mathrm{mL} / \mathrm{d}$ over the first 6 days [34]. Low ambient temperature of $4^{\circ} \mathrm{C}$ might cause a low methane oxidation rate.

Mixed culture may be another reason for the high methane oxidation rate in this study. Much research on AOM mechanisms is based on the isolation and purification of related microorganisms - cultivation that often takes a very long time [25-28]. To reveal the mechanisms of denitrification-dependent AOM (DAOM) and iron-dependent AOM, the enrichment cultures were isolated and purified over 16 months continuously $[18,37]$. In this study, the enrichment culture was achieved by batch cultivation in a short time ( 2 weeks), without the isolation and purification of AOM-related microorganisms. Further studies on the changes of methane oxidation rate and microbial population after subculture and purification are needed.

\section{The Stoichiometry of Anaerobic Methane Oxidation}

AOM are classified into three types according to electron acceptors, sulfate-dependent AOM (SAOM), DAOM, and iron-dependent AOM [32]. The type of AOM is often proved and determined using stoichiometric analysis [18, 37]. The stoichiometric analysis showed that the amount of methane oxidation exceeded the maximum possible number of various electron acceptors in the cultivation system. $\mathrm{Na}_{2} \mathrm{SO}_{4}$ was added to NMS medium as an electron acceptor of AOM. The number of moles of added $\mathrm{Na}_{2} \mathrm{SO}_{4}$ was $12.7 \%$ that of methane in the bottles. According to the mechanism of SAOM, the maximum methane oxidation rate should be $12.7 \%$ (Table 2). However, the 14-day methane oxidation rates for MA1 and MA2 were 36.28\% and $39.40 \%$, respectively (Fig. 2). The amount of oxidized methane was obviously more than the amount of added $\mathrm{Na}_{2} \mathrm{SO}_{4}$.

Based on the existing anaerobic methane oxidation mechanisms, $\mathrm{SO}_{4}^{2-}, \mathrm{NO}_{3}^{-}$, and $\mathrm{PO}_{4}^{3-}$ in the NMS medium also acted as electron receptors [32]. Considering all the possible electron receptors in the NMS medium, the maximum possible oxidation rate was $39.5 \%$. This showed there were various types of AOM in the culture, including SAOM and DAOM. Iron-dependent AOM should also occur because the anaerobic methane oxidation rate was found to be over $50 \%$ in some subsequent subcultures. Metal irons, such as $\mathrm{Fe}^{3+}$ and $\mathrm{Mn}^{4+}$, could be derived into the medium from the inoculated leachate. The chemical forms construction of $\mathrm{Fe}$ and $\mathrm{Mn}$ in the landfill and the contribution of $\mathrm{Fe}^{3+}$ and $\mathrm{Mn}^{4+}$ to methane oxidation should be further studied in the future.

\section{Community Structure of Methane Oxidation Microorganisms}

Microbial community analysis of the enrichment cultures was conducted by high-throughput pyrosequencing, which yielded 297,518 reads with an average length of $440.7 \mathrm{bp}$ for each read. 148,759 valid reads were obtained for subsequent analysis. Referencebased chimera detection was performed using Silva's

Table 3. Recovered sequences, OTUs, and richness/diversity estimators of the culture samples (16S rRNA genes).

\begin{tabular}{|c|c|c|c|c|c|c|}
\hline Samples & $\begin{array}{c}\text { Read } \\
\text { number }\end{array}$ & $\begin{array}{c}\text { Average length } \\
\text { /bp }\end{array}$ & $\begin{array}{c}\text { OTU } \\
\text { number }\end{array}$ & $\begin{array}{c}\text { Richness index/ } \\
\text { ACE }\end{array}$ & $\begin{array}{c}\text { Diversity index/ } \\
\text { Shannon }\end{array}$ & $\begin{array}{c}\text { Coverage } \\
/ \%\end{array}$ \\
\hline MO1 & 34155 & 439.52 & 152 & 88.9 & 1.505 & $99.95 \%$ \\
\hline MO2 & 37382 & 429.46 & 67 & 76.9 & 1.049 & $99.97 \%$ \\
\hline MA1 & 41581 & 445.88 & 91 & 98.8 & 1.984 & $99.97 \%$ \\
\hline MA2 & 35641 & 443.93 & 97 & 101.7 & 2.384 & $99.98 \%$ \\
\hline
\end{tabular}


representative set of $16 \mathrm{~S}$ rRNA gene sequences, and the valid reads were clustered in operational taxonomy units (OTUs) at 97\% similarity. Representative sequences for each OTU (163 OTUs retrieved) were aligned and their taxonomy was assigned using the Silva database. A phylogenetic tree was then constructed using META5.1.

On the whole, the microbial richness and diversity of all enrichment cultures were low (Table 2). The ACE index values of MA were higher than those of MO, indicating that microbial species richness was higher in the anaerobic cultures. According to the Shannon index, species diversity of the aerobic culture was lower. The dominance of main bacteria in aerobic culture samples was higher, and the enrichment effect of oxidizing bacteria was more obvious.

As shown in Fig. 3, Proteobacteria was the dominant group at the phylum level in all samples (relative abundance of 51.26-97.93\%), followed by Bacteroidetes $(1.35-44.76 \%)$, Chloroflexi $(8.69 \%$ in MA), and Actinobacteria $(5.47 \%$ in $\mathrm{MA})$, together accounting for $98.95-99.95 \%$ of all the classified sequences. For the dominant bacterial phylum, Plantomycetes, there were different subgroups in different samples. Betaproteobacteria was the most abundant clade in MO1 and MA2 (41.4-69.4\%), Alphaproteobacteria was the most abundant in $\mathrm{MO}$ 2, and Gammaproteobacteria was the most abundant in MA1.

The majority of Proteobacteria sequences in the aerobic samples were attributed to aerobic methanotrophs. Genus Methylocystis was the most dominant clade in MO1 and MO2 (35.96\% and 78.37\%, respectively). Methylocystis has been found in landfill environments, and Methylocystis strain JTA1 was isolated from the Laogang landfill in Shanghai (China), and can utilize methane as well as acetate [38]. In MO1, Methylophilus (42.45\%) was more dominant than Methylocystis (35.96\%). Moheibacter (41.38\%) and Cupriavidus (43.08\%) were the most dominant genera of MA1 and MA2, respectively. Methanotrophs were a minor component of anaerobic samples, with $29.68 \%$ Methylocaldum in MA1 and 6.36\% Methylocystis in MA2. A total of 212 metabolic pathways were detected

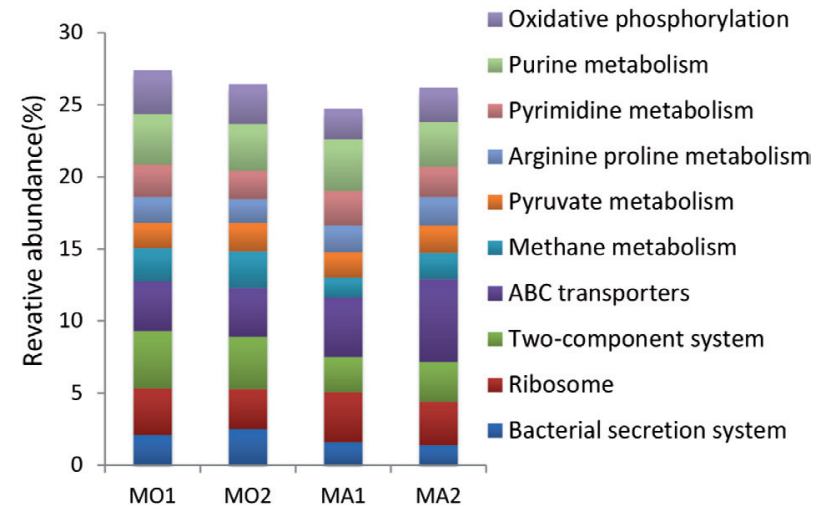

Fig. 4. Top 9 pathways based on $16 \mathrm{~S}$ rRNA bacterial sequence analysis.

in all samples. Methane metabolism was one of the main pathways in each sample (Fig. 4). This indicated that methane metabolism was the main and important metabolic process of nutrition in the samples. The relative abundance (2.28-2.55\%) of methane metabolism in aerobic samples was significantly higher than that in anaerobic samples (1.39-1.81\%).

No research has pointed out the relationship between Moheibacter and Cupriavidus with AOM microorganisms. Moheibacter was detected in underground rocks of the Mohe permafrost area, where there is a great potential for gas hydrate accumulation [39]. The discovered strain was aerobic bacteria, which could hydrolyze casein and other proteins, but could not reduce nitrate or sulfate. This should be related to organic matter degradation in the leachate. Cupriavidus is a widespread genus with oxidative metabolism and can grow in the moist and oligotrophic environment. It has been found to be resistant to metals. Some strains can oxidize ferrous in nitrate environment and reduce arsenic, and some resist cadmium [40]. So they can be used to control soil heavy metal pollution. The influence of these two groups on AOM can be further investigated through subcultures.

Microbial community analysis of pmoA gene sequences for $\mathrm{MO}$ resulted in only 3 OTUs. OTU2
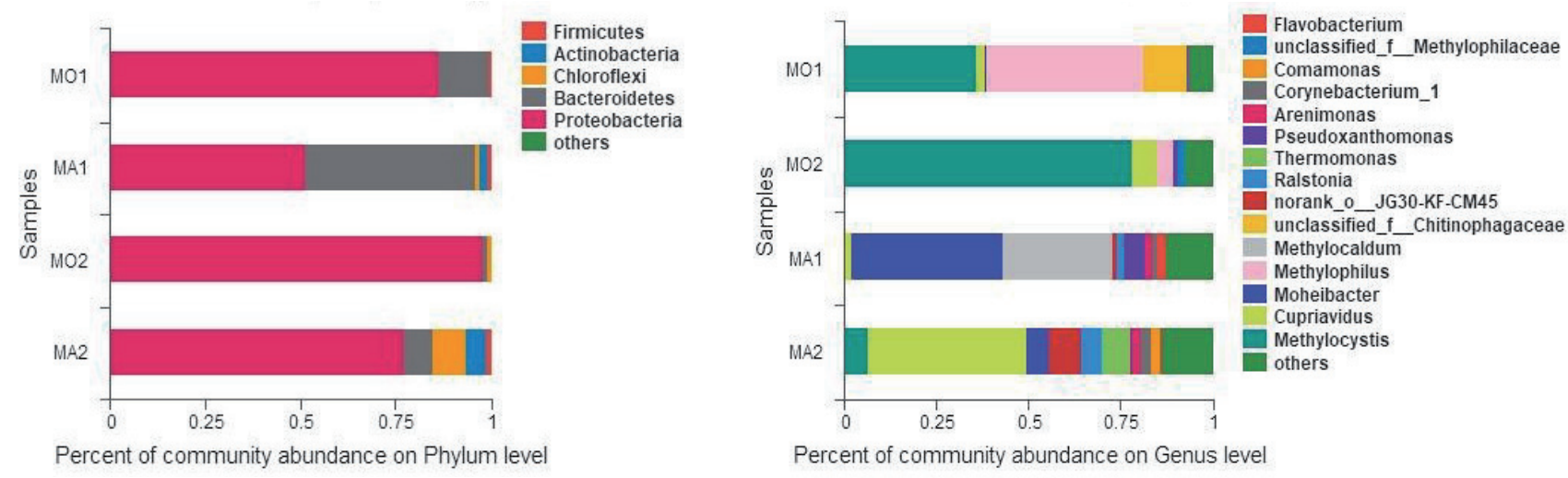

Fig. 3. 16S rRNA bacterial community composition of enriched cultures. 


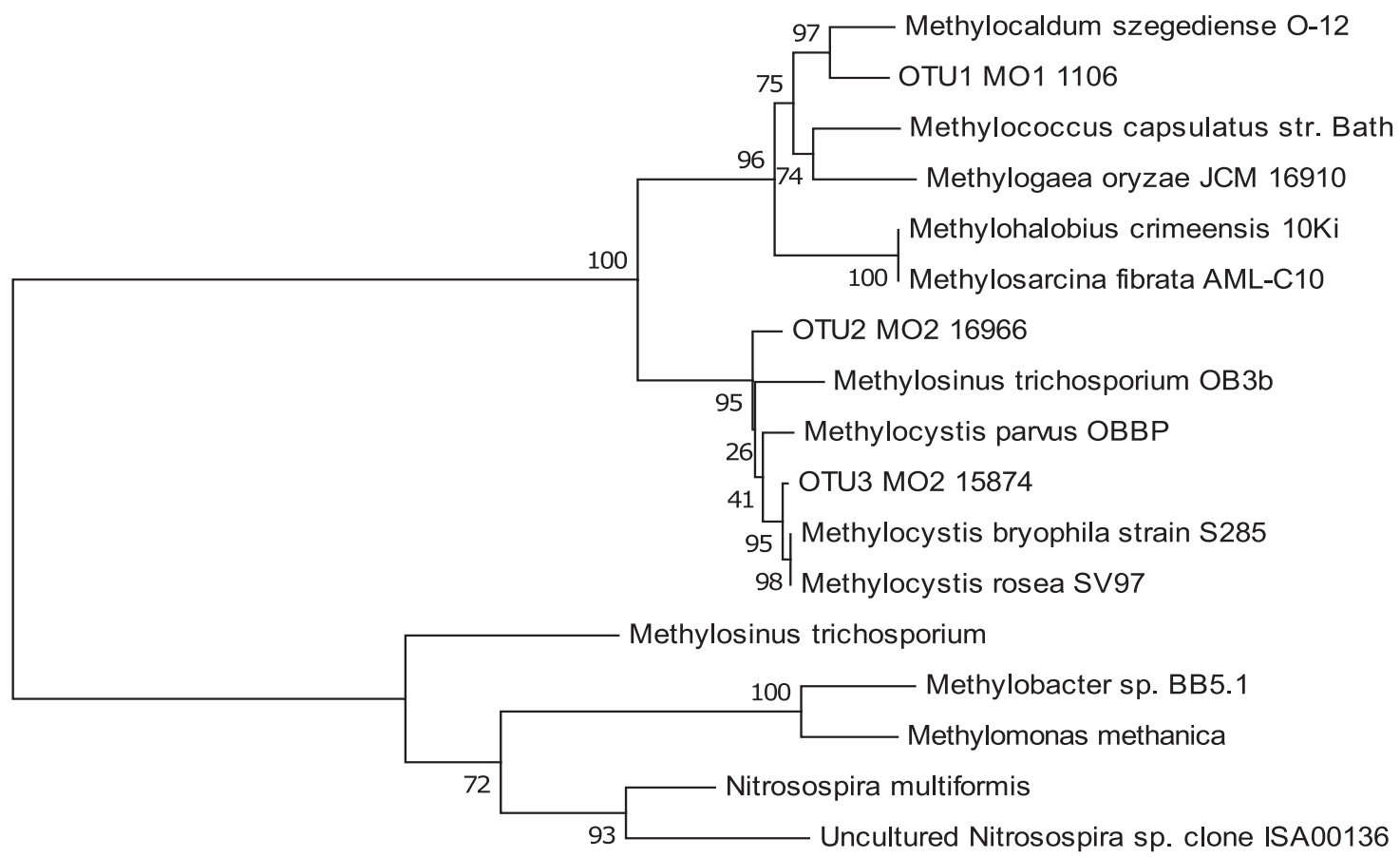

0.2

Fig. 5. Phylogenetic analysis of pmoA gene clone sequences retrieved from enrichment culture; bootstrap values are shown near the clades, and the bar indicates the estimated number of base changes per nucleotide sequence position.

$(99.37 \%)$ and OTU3 (99.28\%) were the dominant populations in $\mathrm{MO} 1$ and $\mathrm{MO} 2$, respectively. Related and similar sequences for the representative sequences of these 3 OTUs obtained from the NBCI database, a phylogenetic tree was constructed (Fig. 5). OTU2 and OTU3 were similar to Methylocystis sp. found in other studies, and were also similar to Methylosinus trichosporium OB3b (the sequence similarities were $94 \%$ and $95 \%$, respectively). This difficulty in classifying methane-oxidizing organisms has been found in other studies. Carlos also found this while comparing Methylocystis parvus OBBP and Methylocystis sp. strain Rockwell and suggested that both species should be taxonomically classified in different genera [41]. OTU1 was Methylocaldum and its relative abundance $(0.17 \%)$ in $\mathrm{MO} 2$ was very low.

Aerobic methanotrophs were found in anaerobic samples in this study. Some previous research also suggest that AOM is a complex process, with more related microbes than previously thought. Aerobic methanotrophs such as Methylobacter have been proven to be involved in AOM [42-47]. Martinez-Cruz et al. studied the microorganisms involved in AOM in subArctic lake sediments using DNA- and phospholipidfatty acid (PLFA)-based stable isotope probing. They found that aerobic methanotrophs Methylobacter assimilated carbon from $\mathrm{CH}_{4}$ as one of the main genera, with the mean $\mathrm{AOM}$ rate $1.76 \pm 0.20 \mu \mathrm{g} / \mathrm{g} \mathrm{dw} / \mathrm{d}$ according to the slope of ${ }^{13} \mathrm{CH}_{4}$ abundance [42].
Aerobic methanotrophs have been previously recognized to perform methane oxidation under anoxic conditions in lake sediments, and active Methylobactertype methanotrophs have been found in anoxic and oxic zones in different lakes [43, 44]. Methylobacter, together with Methylotenera-type methanotrophs, were identified as the dominant genera in incubations with low initial $\mathrm{O}_{2}$ concentrations [45]. Svenning et al. found that a Methylobacter genome also encodes respiratory $\mathrm{NO}_{3}{ }^{-}$and $\mathrm{NO}_{2}^{-}$reductases; therefore, denitrification might be the key to the presence of Methylobacter in anaerobic environments [46, 47]. But the concentrations of $\mathrm{NO}_{3}^{-}$and $\mathrm{NO}_{2}^{-}$were too low to account for the observed $\mathrm{CH}_{4}$ oxidation occurring at $\mathrm{O}_{2}$ concentrations below detection limit.

In our study, aerobic methanotrophs such as genus Methylocaldum and Methylocystis were found to be involved in AOM according to the $16 \mathrm{~S}$ rRNA analysis. The stoichiometry of anaerobic methane oxidation also indicated the complexity of AOM mechanisms in this process. These results suggest the need for further studies regarding the role of aerobic methanotrophs in AOM.

\section{Morphological Characteristics of Methane-Oxidizing Microorganisms}

In the SEM images (Fig. 6), microorganisms in both the aerobic and anaerobic samples were connected by extracellular organic matter in a polymerization state. 


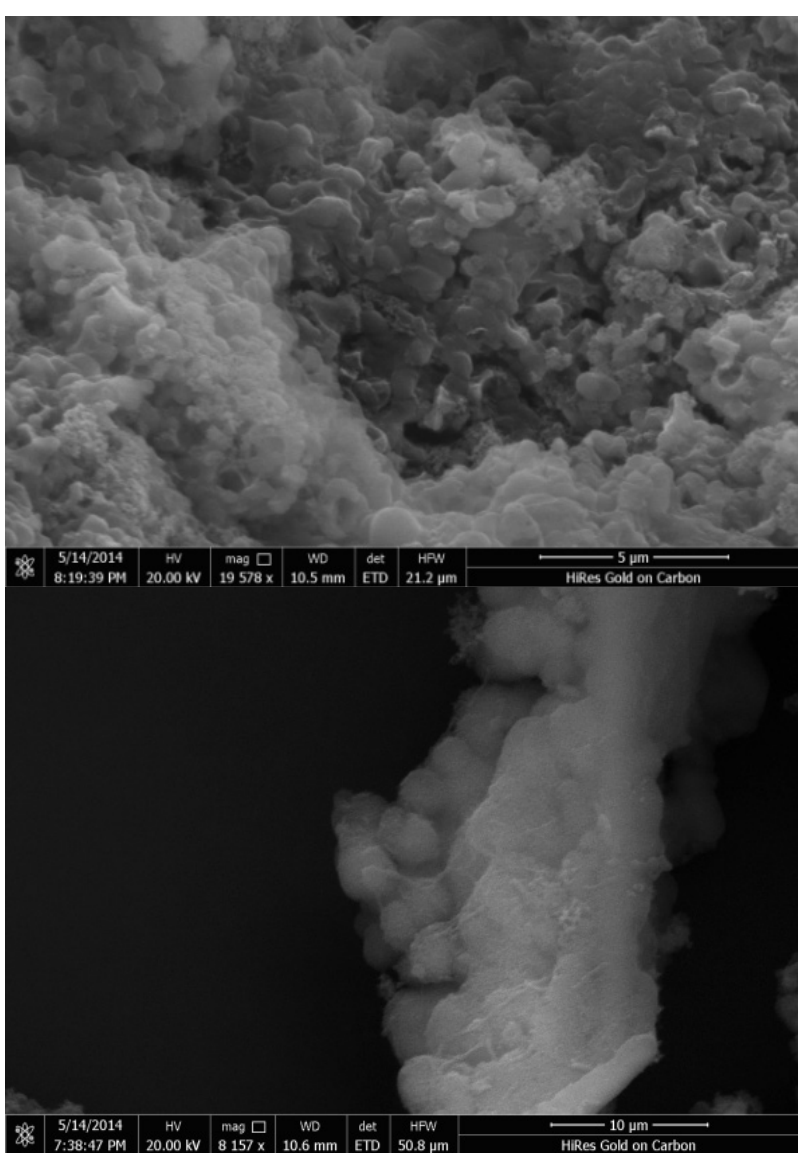

Fig. 6. SEM images of microbial groups in the culture liquid; the left is the MO sample, the right is the MA sample.

The morphological characteristics of the microbes in the aerobic sample could be distinguished by the scattered bacteria on the surface. The cells were rodshaped, with a round-bowl-shaped concave in the center. Cell diameter ranged from 0.4-0.8 $\mu \mathrm{m}$. These features were the same as Methylocystis strain JTA1 in the aged refuse [38]. This result is in accordance with the sequencing analysis [48].

Larger particles (diameter 4.5-7 $\mu \mathrm{m}$ ) were found in the anaerobic samples. These spherical particles were formed by aggregated microbes with an outer cover [49], and it was difficult to identify the morphological characteristics and types of microorganisms. SEM analysis showed that these aggregates were associated with inorganic minerals, indicating that methane oxidation was accompanied by a mineralization process.

\section{Conclusions}

Both aerobic and anaerobic methane oxidation were detected in the landfill environment by the enrichment cultivation method. Methane oxidation rates of aerobic cultures (14-day average oxidation rate 56-77\%) were higher than those of anaerobic cultures (36-39\%). The methane oxidation capacity under anaerobic conditions reached $5.24 \mu \mathrm{mol} \mathrm{mL} \mathrm{L}^{-1} \mathrm{~d}^{-1}$, which was obviously higher than the oxidation capacity (below $1 \mu \mathrm{mol} / \mathrm{mL} / \mathrm{d}$ ) measured in enrichment cultivation using leachate without NMS medium. The results showed that it was effective for enriching an anaerobic methane group with NMS as culture medium.

The 16S rRNA gene sequence analysis showed the obvious differences between aerobic and anaerobic cultures. In the samples cultured under anaerobic conditions, methanotrops Methylocystis is the dominant bacteria, with the relative abundance of $35.96-78.37 \%$. In anaerobic cultured samples, Moheibacter $(41.38 \%$ in MA1) and Cupriavidus $(43.08 \%$ in MA2) are the most dominant species. Methanotrophs Methylocaldum and Methylocystis were found in the anaerobic cultured samples, with low relative abundance.

SEM analysis showed that the microbes in the aerobic sample were similar to the Methylocystis strain JTA1 in the aged refuse. In the anaerobic samples, larger particles (diameter 4.5-7 $\mu \mathrm{m}$ ) formed by aggregated microbes with outer cover were found, and it was hard to identify the types of microorganisms.

The stoichiometry of anaerobic methane oxidation indicated the complexity of AOM mechanisms in this experiment. There were various types of $\mathrm{AOM}$ in the culture, including SAOM, DAOM and irondependent AOM. Aerobic methanotrophs such as genus Methylocaldum and Methylocystis were found in anaerobic samples according to the $16 \mathrm{~S}$ rRNA analysis, and further research is needed to confirm whether aerobic methanotrophs can oxidize methane under anaerobic conditions.

\section{Acknowledgements}

This work was financially supported by the National Natural Science Foundation of China (51508367, 51508366) and the Natural Science Foundation of Jiangsu Province (BK20140282, BK20150284).

\section{Conflict of Interest}

The authors declare no conflict of interest.

\section{References}

1. CLOY J.M., SMITH K.A. Greenhouse gas sources and sinks. Encyclopedia of the Anthropocene, 2, 391, 2018.

2. JIANG X., MIRA D., CLUFF D.L. The combustion mitigation of methane as a non- $\mathrm{CO}_{2}$ greenhouse gas. Progress in Energy and Combustion Science, 66 (5), 176, 2018.

3. IPCC (Intergovernmental Panel on Climate Change). Emissions Scenarios, Special Report of the Intergovernmental Panel on Climate Change. Cambridge University Press, UK, 2000. 
4. FENG S., LEUNG A.K., NG C.W.W., LIU H.W. Theoretical analysis of coupled effects of microbe and root architecture on methane oxidation in vegetated landfill covers. Science of The Total Environment, 599-600, 1954-1964, 2017.

5. GEBERT J., GROENGROEFT A., PFEIFFER E. Relevance of soil physical properties for the microbial oxidation of methane in landfill covers. Soil Biology and Biochemistry, 43 (9), 1759, 2011.

6. YARGICOGLU E.N., REDDY K.R. Effects of biochar and wood pellets amendments added to landfill cover soil on microbial methane oxidation: A laboratory column study. Journal of Environmental Management, 193, 19, 2017.

7. SADASIVAM B.Y., REDDY K.R. Adsorption and transport of methane in landfill cover soil amended with waste-wood biochars. Journal of Environmental Management, 158, 11, 2015.

8. MEI J., ZHEN G.Y., ZHAO Y.C. Bio-oxidation of Escape Methane from Landfill Using Leachate-Modified Aged Refuse. Arabian Journal for Science and Engineering, 41, 2493, 2016.

9. HAN D., ZHAO Y.C., XUE B.J., CHAI X.L. Effect of biocolumn composed of aged refuse on methane abatement - a novel configuration of biological oxidation in refuse landfill. Journal of Environmental Sciences-China, 22, 769, 2010.

10. MEI J., WANG L., HAN D., ZHAO Y.C. Methanotrophic community structure of aged refuse and its capability for methane bio-oxidation. Journal of Environmental Sciences-China, 23, 868874, 2011.

11. KARAKURT I., AYDIN G., AYDINER K. Sources and mitigation of methane emissions by sectors, A critical review. Renewable Energy, 39, 40, 2012.

12. HE Y., LI M., PERUMAL V., FENG X., FANG J., XIE J., SIEVERT S.M., WANG F. Genomic and enzymatic evidence for acetogenesis among multiple lineages of the archaeal phylum Bathyarchaeota widespread in marine sediments. Nature Microbiology, 1 (6), 16035, 2016.

13. SMITH R.L., HOWES B.L., GARABEDIAN S.P. In situ measurement of methane oxidation in groundwater by using natural-gradient tracer tests. Applied and Environmental Microbiology, 57, 1997, 1991.

14. TEICHERT B.M.A., CHEVALIER N., GUSSONE N. Sulfate-dependent anaerobic oxidation of methane at a highly dynamic bubbling site in the Eastern Sea of Marmara (Çinarcik Basin). Deep Sea Research Part II: Topical Studies in Oceanography, Available online, 2017.

15. XU S., LU W.J., MUHAMMAD F.M., LIU Y.T., GUO H.W., MENG R.H., WANG H.T. New molecular method to detect denitrifying anaerobic methane oxidation bacteria from different environmental niches. Journal of Environmental Sciences, 65, 367, 2018.

16. LASH G.G. Pyritization induced by anaerobic oxidation of methane (AOM) - An example from the upper devonian shale succession, western New York, USA. Marine and Petroleum Geology Part A, 68, 520, 2015.

17. MA R., HU Z., ZHANG J., MA H., JIANG L., RU D. Reduction of greenhouse gases emissions during anoxic wastewater treatment by strengthening nitrite-dependent anaerobic methane oxidation process. Bioresource Technology, 235, 211, 2017.

18. ETTWIG K.F., ZHU B.L., SPETH D., KELTJENS J.T., JETTEN M.S.M., KARTAL B. Archaea catalyze irondependent anaerobic oxidation of methane. Proceedings of the National Academy of Sciences, 113 (45), 12792, 2016.

19. SCHOLL M.A., COZZARELLI I.M., CHRISTENSON S.C. Recharge processes drive sulfate reduction in an alluvial aquifer contaminated with landfill leachate. Journal of Contaminant Hydrology, 86, 239, 2006.

20. RANSOM-JONES E., MCDONALD J.E. Draft Genome Sequence of Clostridium sp. Strain W14A Isolated from a Cellulose-Degrading Biofilm in a Landfill Leachate Microcosm. Genome Announcements, 4 (5), 00985, 2016.

21. HAN D., SHI F., CHAI X.L., CHEN H., ZHAO Y.C. A new way of natural mitigation of methane in a refuse landfill, Anaerobic and aerobic co-oxidation. Acta Scientiae Circumstantiae, 31 (4) , 791, 2011 [In Chinese].

22. MILUCKA J., FERDELMAN T.G., POLERECKY L., FRANZKE D., WEGENER G., SCHMID M., LIEBERWIRTH I., WAGNER M., WIDDEL F., KUYPERS M.M.M. Zero-valent sulphur is a key intermediate in marine methane oxidation. Nature, 491, $541,2012$.

23. MCGLYNN S.E., CHADWICK G.L., KEMPES C.P., ORPHAN V.J. Single cell activity reveals direct electron transfer in methanotrophic consortia. Nature, 526, 531, 2015.

24. WEGENER G., KRUKENBERG V., RIEDEL D., TEGETMEYER H.E., BOETIUS A. Intercellular wiring enables electron transfer between methanotrophic archaea and bacteria, Nature, 526, 587, 2015.

25. NORĐI K.À., THAMDRUP B., SCHUBERT C.J. Anaerobic oxidation of methane in an iron rich Danish freshwater lake sediment. Limnology and Oceanography, 58 (2), 546, 2013.

26. TORRES N.T., OCH L.M., HAUSER P.C., FURRER G., BRANDL H., VOVOGINA E., STURM M., BÜRGMANN H., MÜLLER B. Early diagenetic processes generate iron and manganese oxide layers in the sediments of Lake Baikal, Siberia. Environmental Science Processes \& Impacts, 16 (4), 879, 2014.

27. AMOS R.T., BEKINS B.A., COZZARELLI I.M., COZZARELLI I.M., KIRSHTEIN J.D., JONES E.J.P.,\& BLOWES D.W. Evidence for iron-mediated anaerobic methane oxidation in a crude oil-contaminated aquifer. Geobiology, 10 (6), 506, 2012.

28. CHANG Y.H, CHENG T.W., LAI W.J., TSAI W.Y., SUN C.H., LIN L.H., WANG P.L. Microbial methane cycling in a terrestrial mud volcano in eastern Taiwan. Environmental Microbiology, 14 (4), 8958, 2012.

29. ZHAO Y.C., LOU Z.Y. Pollution control and resource recovery: municipal solid wastes at landfill, UK: Elsevier Publisher Inc, 2016.

30. COSTEllO A.M., LIDSTROM M.E. Molecular characterization of functional and phylogenetic genes from natural populations of methanotrophs in lake sediments. Applied and Environmental Microbiology, 65 (11), 5066, 1999.

31. STRALISPAVESE N., BODROSSY L., REICHENAUER T.G., WEILHARTER A. A Sessitsch 16S rRNA based T-RFLP analysis of methane oxidising bacteriaAssessment, critical evaluation of methodology performance and application for landfill site cover soils, Applied Soil Ecology, 31 (3), 251, 2006.

32. ONI O.E., FRIEDRICH M.W. Metal Oxide Reduction Linked to Anaerobic Methane Oxidation. Trends in Microbiology, 25 (2), 88=, 2017.

33. MALYAN S.K., BHATIA A., KUMAR A., GUPTA D.K., SINGH R. Methane production, oxidation and mitigation: A mechanistic understanding and comprehensive evaluation of influencing factors. Science of The Total Environment, 572, 874, 2016. 
34. SCHELLER S., YU H., CHADWICK G.L., MCGLYNN S.E.,ORPHAN V.J. Artificial electron acceptors decouple archaeal methane oxidation from sulfate reduction. Science, 351 (6274), 703, 2016.

35. APHA; Standard Methods for the Examination of Water and Waste Water. Washington, DC, 1998.

36. LOU, Z.Y., ZHAO, Y.C., YUAN, T., SONGY., CHEN H.L., ZHU N.W., HUANG R.H. Natural attenuation and characterization of contaminants composition in landfill leachate under different disposing ages. Science of The Total Environment, 407 (10), 3385, 2009.

37. RAGHOEBARSING A.A., POL A., PAS-SCHOONEN K.T., SMOLDERS A.J.P., ETTWIG K.F., RIJPSTRA W.I.C., SCHOUTEN S., DAMSTE J.S.S., CAMP H.J.M.O., JETTEN M.S.M., STROUS M. A microbial consortium couples anaerobic methane oxidation to denitrification. Nature, 440 (7086), 918, 2006.

38. ZHAO T.T., ZHANG L.J., ZHANG Y.R. Characterization of Methylocystis strain JTA1 isolated from aged refuse and its tolerance to chloroform. Journal of Environmental Sciences, 25 (4), 770, 2013.

39. ZHANG R.G., TAN X., ZHAO X.M., DENG J., LV J. Moheibacter sediminis gen. nov., sp. nov., a member of the family Flavobacteriaceae isolated from sediment, and emended descriptions of Empedobacter brevis, Wautersiella falsenii and Weeksella virosa. International journal of systematic and evolutionary microbiology, 64 (5), 1481, 2014.

40. VANDAMME P., COENYE T. Taxonomy of the genus Cupriavidus: a tale of lost and found. International journal of systematic and evolutionary microbiology, 54 (6), 2285, 2004.

41. CERRO C., GARCÍA J.M., ROJAS A., TORTAJADA M., RAMÓN D., GALÁN B., PRIETO M.A., GARCÍA J.L. Genome sequence of the methanotrophic poly-betahydroxybutyrate producer Methylocystis parvus OBBP. Journal of Bacteriology, 194 (20), 5709, 2012.
42. MARTINEZ-CRUZ K., LEEWIS M., HERRIOTT I.C., SEPULVEDA-JAUREGUI A., ANTHONY K.W., THALASSO F., LEIGH M.B. Anaerobic oxidation of methane by aerobic methanotrophs in sub-Arctic lake sediments. Science of The Total Environment, 607-608, 23, 2017.

43. OSWALD K., MILUCKA J., BRAND A., HACH P., LITTMANN S., WEHRLI B., KUYPERS M., SCHUBERT C. Aerobic gammaproteobacterial methanotrophs mitigate methane emissions from oxic and anoxic lake waters. Limnology and Oceanography, 61, S101, 2016.

44. HE R., WOOLLER M.J., POHLMAN J.W., CATRANIS C., QUENSEN J., TIEDJE J.M., LEIGH M.B. Identification of functionally active aerobic methanotrophs in sediments from an arctic lake using stable isotope probing. Environmental Microbiology, 14 (6), 1403, 2012.

45. HERNANDEZ M.E., BECK D.A.C., LIDSTROM M.E., LUDMILA C. Oxygen availability is a major factor in determining the composition of microbial communities involved in methane oxidation. Peerj, 3 (2), e801, 2015.

46. SVENNING M.M., HESTNES A.G., WARTIAINEN I., STEIN L.Y., KLOTZ M.G., et al. Genome sequence of the Arctic Methanotroph Methylobacter tundripaludum SV96. Joural of Bacteriology, 193 (22), 6418, 2011.

47. KALYUZHNAYA M.G., LAMB A.E., MCTAGGART T.L., et al. Draft genomes of gammaproteobacterial methanotrophs isolated from Lake Washington sediment. Genome Announc, 3 (2), e00103, 2015.

48. RICHARD S.H., THOMAS E.H. Methanotrophic Bacteria. Microbiological Reviews, 439, 1996.

49. KNITTEL K., LÖSEKANN T., BOETIUS A. Diversity and Distribution of Methanotrophic Archaea at Cold Seeps. Applied \& Environmental Microbiology, 71 (1), 467, 2005. 